\title{
Glycosidase Activities in the Livers of Various Fishes and Mollusks
}

\author{
Hiroki Nakagawa, ${ }^{* 1}$ Makio Asakawa, ${ }^{* 2}$ and Noriyuki Enomoto*1 \\ (Accepted October 2, 1986)
}

\begin{abstract}
Glycosidases are useful for structural and functional studies of glycoproteins and glycolipids. To explore the highly suitable glycosidase sources among marine animals, glycosidase activities in the livers of various fishes and some mollusks were measured. Relatively high activities of various glycosidases were found in all the livers examined. $\beta$ - $N$-Acetylhexosaminidase activity was extremely high in the livers of common octopus, sea breams, croaker, and common squid. $\alpha-N$-Acetylgalactosaminidase activity was fairly high in all the livers and most dominant in skipjack liver. $\beta$-Galactosidase and $\alpha$-mannosidase activities were also sufficiently high in the livers of sea breams, common octopus, common squid, yellowtail, and common horse mackerel to use these livers as the enzyme source. The extractability of glycosidases increased by approximately $20 \%$ after moderate autolysis of the livers.
\end{abstract}

Glycosidases, which cleave the monosaccharide units from the nonreducing termini of the heterosaccharide chains of glycoproteins and glycolipids, are a powerful tool available for elucidation of the anomeric configuration and sequential arrangement of monosaccharide units in the heterosaccharide chains. ${ }^{1)}$ To date, a number of glycosidases have been isolated from various enzyme sources. However, very little is known about glycosidases of fishes. Glycosidases with broad aglycon specificity are particularly valuable for structural and functional studies of the heterosaccharide chains, since such glycosidases effectively act on natural substrates such as glycoproteins and glycolipids.2) Glycosidases from marine animals are assumed to have broad aglycon specificity. ${ }^{2)}$

To explore the highly suitable sources for glycosidases among marine animals, glycosidase activities in the livers of various fishes and some mollusks were measured. This paper reports the glycosidase activities in these livers and the highly suitability of some of the livers for glycosidase sources.

\section{Materials and Methods}

\section{Substrates}

$p$-Nitrophenyl $\beta$-D- $N$-acetylglucosaminide and $p$ - nitrophenyl $\quad \alpha-\mathrm{D}-N$-acetylgalactosaminide were purchased from Koch-Light Laboratories Ltd. $p$-Nitrophenyl $\alpha$ - and $\beta$-D-mannopyranosides, $p$ nitrophenyl $\alpha$ - and $\beta$-D-galactopyranosides, and $p$-nitrophenyl $\alpha$-L-fucopyranoside were purchased from Nakarai Chemicals Ltd.

\section{Livers of Fishes and Mollusks}

The fresh livers of various fishes and mollusks were obtained from fish stores and stored in a freezer for a short time until use.

\section{Acetone Powders of Livers}

Fresh liver was homogenized with 5 volumes of acetone and filtered. The residue on the filter was repeatedly washed with acetone and dried under reduced pressure. The dry residue was crushed in a porcelain mortar. The acetone powder was stored in a freezer.

\section{Extraction of Glycosidases}

All operations were carried out below $5^{\circ} \mathrm{C}$. The acetone powder was sufficiently swollen with a small volume of $0.05 \mathrm{~m}$ sodium citrate buffer, $\mathrm{pH} 4.6$, and then homogenized in a blender (Sakuma Seisakusho) for $2 \mathrm{~min}$ at the top speed with $25 \mathrm{ml}$ of the same buffer per $1 \mathrm{~g}$ of the powder. In the case of fresh liver, the liver was homogenized with $5 \mathrm{ml}$ of the same buffer per $1 \mathrm{~g}$ of the

*1 Department of Agricultural Chemistry, Faculty of Agriculture, Saga University, Honjo, Saga 840, Japan (中川浩毅，榎本則行：佐賀大学露学部震芸化学科).

*2 Laboratory of Food Science, Faculty of Education, Kumamoto University, Kurokami, Kumamoto 860, Japan (浅川牧夫: 熊本大学教育学部食物学数室). 
Table 1. Glycosidase activities in the livers of fishes and mollusks

\begin{tabular}{|c|c|c|c|c|c|c|c|}
\hline \multirow[b]{2}{*}{ Fish name } & \multicolumn{7}{|c|}{ Units/g of acetone powder } \\
\hline & $\alpha-\operatorname{Man}$ & $\alpha-\mathrm{Gal}$ & $\begin{array}{c}\alpha-N- \\
\text { Acgal }\end{array}$ & $\beta$-Gal & $\begin{array}{c}\beta-N- \\
\text { Achex }\end{array}$ & $\alpha$-Fuc & $\beta$-Man \\
\hline Madai (red sea bream, Pagrus major) & 5.2 & 4.1 & 21.0 & 11.2 & 181 & 3.6 & 5.8 \\
\hline Madai (red sea bream, Pagrus major) & 4.3 & 3.5 & 16.0 & 7.6 & 125 & 3.1 & 3.4 \\
\hline Kidai (yellow sea bream, Dentex tumifrons) & 4.1 & 4.2 & 30.0 & 12.5 & 156 & 5.1 & 4.5 \\
\hline $\begin{array}{l}\text { Kurodai (black sea bream, } \\
\text { Acanthopagrus schlegeli) }\end{array}$ & 3.8 & 3.8 & 17.0 & 14.0 & 128 & 5.2 & 5.7 \\
\hline Katsuo (skipjack, Katsuwonus pelamis) & 4.7 & 2.2 & 36.0 & 2.8 & 26.2 & 1.3 & 1.6 \\
\hline Katsuo (skipjack, Kastuwonus pelamis) & 2.8 & 3.4 & 26.1 & 3.7 & 21.0 & 1.5 & 2.0 \\
\hline Hamachi (yellowtail, Seriola quinqueradiata) & 5.2 & 1.3 & 10.2 & 11.5 & 70.2 & 1.8 & 1.8 \\
\hline Hamachi (yellowtail, Seriola quinqueradiata) & 3.5 & 1.4 & 8.0 & 7.5 & 54.0 & 1.9 & 1.7 \\
\hline Masaba (pacific mackerel, Scomber japonicus) & 1.9 & 1.7 & 9.2 & 4.5 & 44.3 & 1.4 & 1.0 \\
\hline $\begin{array}{l}\text { Maaji (common horse mackerel, } \\
\text { Trachurtus japonicus) }\end{array}$ & 6.2 & 5.3 & 15.5 & 11.0 & 74.0 & 2.9 & 3.8 \\
\hline Koichi (croaker, Nibea albiflora) & 2.6 & 4.6 & 16.0 & 4.5 & 220 & 4.0 & 0.8 \\
\hline Kanpachi (amberjack, Seriola dumerili) & 6.0 & 4.8 & 6.7 & 8.4 & 110 & 3.3 & 2.8 \\
\hline Suzuki (sea bass, Lateolabrax japonicus) & 2.1 & 1.8 & 11.4 & 7.0 & 38.7 & 7.7 & 4.0 \\
\hline Hirame (flounder, Paralichthys olivaceus) & 3.0 & 2.4 & 7.2 & 4.8 & 14.8 & 1.9 & 0.7 \\
\hline Tachiuo (hairtail, Trichiurus lepturus) & 2.9 & 1.6 & 7.0 & 5.2 & 23.0 & 2.1 & 1.5 \\
\hline Mafugu (globefish, Takifugu porphyreus) & 2.3 & 1.8 & 4.6 & 4.6 & 28.2 & 3.1 & 3.9 \\
\hline Shïra (dorado, Coryphaena hippurus) & 4.3 & 4.0 & 15.1 & 10.0 & 90.4 & 2.8 & 3.1 \\
\hline Madako (common octopus, Octopus vulgaris) & 13.7 & 2.5 & 9.6 & 12.4 & 255 & 4.0 & 2.3 \\
\hline Madako (common octopus, Octopus vulgaris) & 9.2 & 2.3 & 7.0 & 8.4 & 135 & 3.3 & 1.4 \\
\hline $\begin{array}{l}\text { Surumeika (common squid, } \\
\text { Todarodes pacificus) }\end{array}$ & 5.0 & 1.5 & 17.5 & 13.1 & 124 & 5.3 & 1.2 \\
\hline $\begin{array}{l}\text { Surumeika (common squid, } \\
\text { Todarodes pacificus) }\end{array}$ & 4.1 & 1.4 & 18.2 & 10.4 & 95 & 4.1 & 1.3 \\
\hline Sazae (top shell, Turbo cornutus) & 6.5 & 4.2 & 7.2 & 11.1 & 37.0 & 5.1 & 7.0 \\
\hline Tengunishi (top shell, Hemifusus ternatanus) & 7.7 & 3.5 & 11.7 & 14.0 & 32.0 & 3.7 & 12.5 \\
\hline
\end{tabular}

tissue. The homogenate was centrifuged at $15,000 \times \mathrm{g}$ for $30 \mathrm{~min}$ to obtain the clear supernatant which was used for assays of glycosidase activities.

\section{Enzyme Assays}

Activities of glycosidases were assayed at $37^{\circ} \mathrm{C}$ by using the corresponding $p$-nitrophenyl glycoside as substrate. The enzyme solution $(50 \mu l)$ was added to $0.3 \mathrm{ml}$ of $2 \mathrm{mM} p$-nitrophenyl glycoside dissolved in $0.05 \mathrm{~m}$ sodium citrate buffer, $\mathrm{pH} 4.6$. After incubation for a preset time, $3.0 \mathrm{ml}$ of $0.2 \mathrm{M}$ sodium borate buffer, $\mathrm{pH} 9.8$, was added to stop the reaction and the absorbance of the resultant solution was measured at $400 \mathrm{~nm}$. One unit of enzyme was defined as the amount of enzyme which hydrolyzes $1 \mu \mathrm{mol}$ of $p$-nitrophenyl glycoside per min under the conditions described above.

\section{Results and Discussion}

Glycosidase Activities in Livers of Fishes and Mollusks

The glycosidase activities found in the livers of various fishes and mollusks are summarized in Table 1. On the whole, relatively high activities of glycosidases were found in all the livers examined. $\beta-N$-Acetylhexosaminidase activity was very high in all the livers. Particularly, the livers of common octopus, sea breams, croaker, and common squid contained amazingly high activity of the enzyme. Consequently, these livers may be very good sources for the isolation of the enzyme. Actually, we have isolated electrophoretically homogeneous $\beta$ - $N$-acetylhexosaminidase from common octopus iver by the simple purification procedure. ${ }^{3)}$

$\alpha-N$-Acetylgalactosaminidase activity was fairly high in all the livers. The isolation of $\alpha-N$-acetylgalactosaminidase has been considered to be more difficult than that of $\beta$-N-acetylhexosami- 
Table 2. Recoveries of glycosidase activities in the acetone powder from the livers of red sea bream, skipjack, and common octopus

\begin{tabular}{|c|c|c|c|c|c|c|c|c|c|}
\hline \multirow[b]{2}{*}{ Glycosidase } & \multicolumn{3}{|c|}{ Red sea bream } & \multicolumn{3}{|c|}{ Skipjack } & \multicolumn{3}{|c|}{ Common octopus } \\
\hline & $\begin{array}{l}\text { Fresh } \\
\text { liver } \\
\text { T.U. }\end{array}$ & $\begin{array}{l}\text { Acetone } \\
\text { powder } \\
\text { T.U. }\end{array}$ & $\begin{array}{c}\mathrm{Re}- \\
\text { covery } \\
\%\end{array}$ & $\begin{array}{l}\text { Fresh } \\
\text { liver } \\
\text { T.U. }\end{array}$ & $\begin{array}{l}\text { Acetone } \\
\text { powder } \\
\text { T.U. }\end{array}$ & $\begin{array}{l}\text { Re- } \\
\text { covery } \\
\%\end{array}$ & $\begin{array}{l}\text { Fresh } \\
\text { liver } \\
\text { T.U. }\end{array}$ & $\begin{array}{l}\text { Acetone } \\
\text { powder } \\
\text { T.U. }\end{array}$ & $\begin{array}{c}\text { Re- } \\
\text { covery } \\
\%\end{array}$ \\
\hline $\begin{array}{r}\alpha-\text { Mannosidase } \\
\text { [EC 3.2.1.24] }\end{array}$ & 29.6 & 31.1 & 105 & 26.3 & 25.8 & 98 & 73.2 & 75.4 & 103 \\
\hline $\begin{array}{c}\alpha \text {-Galactosidase } \\
\text { [EC 3.2.1.22] }\end{array}$ & 35.0 & 29.4 & 84 & 36.0 & 31.3 & 87 & 20.5 & 18.9 & 92 \\
\hline $\begin{array}{l}\alpha-N \text {-Acetyl- } \\
\text { galactosaminidase } \\
\text { [EC 3.2.1.49] }\end{array}$ & 154 & 134 & 87 & 267 & 240 & 90 & 67.5 & 57.4 & 85 \\
\hline $\begin{array}{c}\beta \text {-Galactosidase } \\
\text { [EC 3.2.1.23] }\end{array}$ & 71.7 & 63.8 & 89 & 39.0 & 35.9 & 92 & 71.8 & 68.9 & 96 \\
\hline $\begin{array}{l}\beta-N \text {-Acetyl- } \\
\text { hexosaminidase } \\
\text { [EC 3.2.1.30] }\end{array}$ & 1141 & 1050 & 92 & 201 & 193 & 96 & 1152 & 1025 & 89 \\
\hline $\begin{array}{l}\alpha \text {-Fucosidase } \\
\text { [EC 3.2.1.51] }\end{array}$ & 32.1 & 26.0 & 81 & 19.4 & 13.8 & 71 & 36.1 & 27.1 & 75 \\
\hline $\begin{array}{r}\beta-\text { Mannosidase } \\
\text { [EC 3.2.1.25] }\end{array}$ & 30.8 & 28.6 & 93 & 22.2 & 18.4 & 83 & 14.9 & 11.5 & 77 \\
\hline
\end{tabular}

nidase. The reason of the difficulty is that besides the instability of the $\alpha-N$-acetylgalactosaminidase activity, the enzyme has not been favored with the suitable sources and that the attainment of complete separation of the enzyme from the dominantly occurring $\beta$ - $N$-acetylhexosaminidase has been extremely difficult. 4,5 ) Skipjack liver contained high activity of $\alpha-N$ acetylgalactosaminidase. In addition, the activity was exceptionally higher than $\beta-N$-acetylhexosaminidase activity. These facts suggest that skipjack liver offers a quite suitable source for the isolation of the enzyme. Actually, we have isolated electrophoretically homogeneous $\alpha-N$ acetylgalactosaminidase which was free from $\beta$ $N$-acetylhexosaminidase. ${ }^{\theta)}$

Judging from our experiences of the enzyme purification, ${ }^{3,8-8)}$ the glycosidases containing more than 5 units per $1 \mathrm{~g}$ of the acetone powder are possible to be isolated from the livers. $\beta$-Galactosidase and $\alpha$-mannosidase activities in the livers of sea breams, common octopus, common squid, yellowtail, and common horse mackerel were sufficiently high to isolate these enzymes. $\beta$ Mannosidase activity was relatively low in all the livers except the liver of top shells. The liver of a top shell, $T$. cornutus, has been a good glycosidase source, from which glycosidases of practical grade such as $\alpha$ - and $\beta$-mannosidase ${ }^{8)}$ and $\beta-N$-acetylhexosaminidase $\left.{ }^{10}\right)$ have been isolated and utilized for the structural analysis of various complex carbohydrates. ${ }^{23}$. In the case of the top shell liver, it is very difficult to separate the liver tissue free from digestive organs. Consequently, the crude enzyme extract contained potent cellulase which made the enzyme purification difficult..$^{\theta, 10}$

\section{Effect of Acetone Treatment on Glycosidass Ac- tivities}

Fresh liver gave a cloudy enzyme extract after centrifugation at $15,000 \times \mathrm{g}$ for $30 \mathrm{~min}$ owing to its high lipid content. On the other hand, the acetone powder of the liver gave a clear enzyme extract to facilitate the subsequent purification procedure. Moreover, the total activities of glycosidases can be preserved for several years when the powder is kept in a freezer. However, losses of glycosidase activities upon the acetone treatment will be unavoidable. To evaluate these losses, the recoveries of glycosidase activities in the acetone powders were determined. The results obtained are summarized in Table 2. The recoveries of the activities of major glycosidases were approximately $90 \%$, indicating that the enzyme activities were little affected by the acetone treatment.

Effect of Autolysis on Extractability of Glycosidases

Glycosidases in mammalian tissues occur mostly in the lysosomes. ${ }^{11}$ ) In such case, it is expected that disruption of the particles by moderate auto- 
Table 3. Increase in extractability of glycosidases by autolysis of livers

\begin{tabular}{|c|c|c|c|c|c|c|c|c|c|}
\hline \multirow[b]{2}{*}{ Glycosidase } & \multicolumn{3}{|c|}{ Red sea bream } & \multicolumn{3}{|c|}{ Skipjack } & \multicolumn{3}{|c|}{ Common octopus } \\
\hline & $\begin{array}{l}\text { Unauto- } \\
\text { lyzed } \\
\text { Units/g }\end{array}$ & $\begin{array}{l}\text { Auto- } \\
\text { lyzed } \\
\text { Units/g }\end{array}$ & $\begin{array}{c}\text { Increase } \\
\% \\
\end{array}$ & $\begin{array}{l}\text { Unauto- } \\
\text { lyzed } \\
\text { Units/g }\end{array}$ & $\begin{array}{l}\text { Auto- } \\
\text { lyzed } \\
\text { Units/g }\end{array}$ & $\begin{array}{c}\text { Increase } \\
\% \\
\end{array}$ & $\begin{array}{l}\text { Unauto- } \\
\text { lyzed } \\
\text { Units/g }\end{array}$ & $\begin{array}{l}\text { Auto- } \\
\text { lyzed } \\
\text { Units/g }\end{array}$ & $\begin{array}{c}\text { Increase } \\
\%\end{array}$ \\
\hline$\alpha$-Mannosidase & 3.7 & 4.5 & 22 & 2.8 & 3.5 & 25 & 9.2 & 11.2 & 22 \\
\hline$\alpha$-Galactosidase & 3.5 & 4.0 & 14 & 3.4 & 4.0 & 18 & 2.3 & 2.8 & 22 \\
\hline $\begin{array}{l}\alpha-N \text {-Acetyl- } \\
\text { galactosaminidase }\end{array}$ & 16.0 & 19.2 & 20 & 26.1 & 31.8 & 22 & 7.0 & 8.8 & 26 \\
\hline$\beta$-Galactosidase & 7.6 & 9.7 & 28 & 3.9 & 4.6 & 18 & 8.4 & 9.9 & 18 \\
\hline $\begin{array}{l}\beta-N \text {-Acetyl- } \\
\text { hexosaminidase }\end{array}$ & 125 & 163 & 30 & 21.0 & 26.5 & 26 & 125 & 160 & 28 \\
\hline$\alpha$-Fucosidase & 3.1 & 3.4 & 10 & 1.5 & 1.7 & 13 & 3.3 & 3.7 & 12 \\
\hline$\beta$-Mannosidase & 3.4 & 4.0 & 18 & 2.0 & 2.4 & 20 & 1.4 & 1.5 & 7 \\
\hline
\end{tabular}

Glycosidase activities were expressed as units per $1 \mathrm{~g}$ of acetone powder.

Table 4. Increase in extractability of glycosidases by standing of homogenates at $5^{\circ} \mathrm{C}$ for $24 \mathrm{~h}$.

\begin{tabular}{|c|c|c|c|c|c|c|c|c|c|}
\hline \multirow{2}{*}{ Glycosidase } & \multicolumn{3}{|c|}{ Red sea bream } & \multicolumn{3}{|c|}{ Skipjack } & \multicolumn{3}{|c|}{ Common octopus } \\
\hline & $\begin{array}{c}\text { Unauto- } \\
\text { lyzed } \\
\text { Units/g }\end{array}$ & $\begin{array}{l}\text { Auto- } \\
\text { lyzed } \\
\text { Units/g }\end{array}$ & $\begin{array}{c}\text { Increase } \\
\%\end{array}$ & $\begin{array}{c}\text { Unauto- } \\
\text { lyzed } \\
\text { Units/g }\end{array}$ & $\begin{array}{l}\text { Auto- } \\
\text { lyzed } \\
\text { Units/g }\end{array}$ & $\begin{array}{c}\text { Increase } \\
\% \\
\end{array}$ & $\begin{array}{l}\text { Unauto- } \\
\text { lyzed } \\
\text { Units/g }\end{array}$ & $\begin{array}{c}\text { Auto- } \\
\text { lyzed } \\
\text { Units/g }\end{array}$ & $\begin{array}{c}\text { Increase } \\
\% \\
\end{array}$ \\
\hline$\alpha$-Mannosidase & 3.7 & 3.9 & 5 & 2.8 & 2.5 & -11 & 9.2 & 10.5 & 14 \\
\hline$\alpha$-Galactosidase & 3.5 & 3.0 & -14 & 3.4 & 3.4 & 0 & 2.3 & 2.3 & 0 \\
\hline $\begin{array}{l}\alpha-N \text {-Acetyl } \\
\text { galactosaminidase }\end{array}$ & 16.0 & 19.8 & 24 & 26.5 & 33.0 & 25 & 7.0 & 8.6 & 23 \\
\hline $\begin{array}{l}\beta \text {-Galactosidase } \\
\beta-N \text {-Acetyl- }\end{array}$ & 7.6 & 8.7 & 14 & 3.9 & 4.3 & 10 & 8.4 & 10.0 & 19 \\
\hline hexosaminidase & 125 & 154 & 23 & 21.0 & 25.0 & 19 & 125 & 156 & 25 \\
\hline$\alpha$-Fucosidase & 3.1 & 1.8 & -42 & 1.5 & 1.2 & -20 & 3.3 & 2.4 & -27 \\
\hline$\beta$-Mannosidase & 3.4 & 2.8 & -18 & 2.0 & 2.1 & 5 & 1.4 & 1.5 & 7 \\
\hline
\end{tabular}

Glycosidase activities were expressed as units per $1 \mathrm{~g}$ of acetone powder.

lysis releases more amounts of glycosidases into the enzyme extract. Hence, the effect of autolysis on the extractability of glycosidases was investigated in the following way. The fresh livers were allowed to stand for $24 \mathrm{~h}$ at $5^{\circ} \mathrm{C}$ prior to the acetone treatment and the glycosidase activities in the acetone powders prepared from the autolyzed livers were assayed. A summary of the results is presented in Table 3. Approximately 10-30\% of the glycosidase activities in the extract increased. This demonstrates that the moderate autolysis effectively increases the extractable glycosidases.

The acetone powders prepared from unautolyzed livers were homogenized with $0.05 \mathrm{M}$ sodium citrate buffer, $\mathrm{pH} 4.6$, and the homogenates were allowed to stand for $24 \mathrm{~h}$ at $5^{\circ} \mathrm{C}$. The glycosidase activities in the homogenates were assayed. $\mathrm{A}$ summary of the results is presented in Table 4. Approximately $20 \%$ of the activities of major glycosidases such as $\beta$ - $N$-acetylhaxosaminidase and $\alpha-N$-acetylgalactosaminidase increased. On the contrary, the activities of minor glycosidases such as $\alpha$-fucosidase and $\beta$-mannosidase decreased.
From these results, the moderate autolysis is effective in increasing the extractable glycosidases. However, it should be noted that excessive autolysis is liable to inactivate glycosidases and to make the enzyme purification more difficult because of the increase in degradation products.

The catabolic degradation of complex carbohydrates such as glycoproteins, proteoglycans, and glycolipids, which are quite ubiquitous in the animal organism, has been postulated to be through the concerted action of exoglycosidases and endoglycosidases. ${ }^{12-14}$ ) Hence, in addition to the exoglycosidases discussed above, endoglycosidases such as endo- $\beta$-galactosidase ${ }^{7,14)}$ and endo- $\beta-N$-acetylglucosaminidase, ${ }^{15)}$ which cleave the heterosaccharide chains to produce small oligosaccharides, are possible to occur in the livers of marine animals.

\section{References}

1) Y.-T. Li and S.-C. Li: in "The Glycoconjugates" (ed. by M. I. Horowitz and W. Pigman), Vol. 1, 
Academic Press, New York, 1977, pp. 52-67.

2) T. Muramatsu: Seikagaku, 48, 1021-1044 (1976).

3) H. Nakagawa, N. Enomoto, and M. Asakawa: Nippon Suisan Gakkaishi, 53, 1025-1031 (1987).

4) Y. Uda, S.-C. Li, and Y.-T. Li: J. Biol. Chem., 252, 5194-5200 (1977).

5) T. Itoh and Y. Uda: J. Biochem., 95, 959-970 (1984).

6) H. Nakagawa, M. Asakawa, and N. Enomoto: J. Biochem., 101, 855-862 (1987).

7) N. Nakagawa, T. Yamada, J.-L. Chien, A. Gardas, M. Kitamikado, S.-C. Li, and Y.-T. Li: J. Biol. Chem., 255, 5955-5959 (1980).

8) T. Itoh, Y. Uda, and H. Nakagawa: J. Biochem., 99, 243-250 (1986),

9) T. Muramatsu and F. Egami: J. Biochem., 62,
700-709 (1967).

10) T. Muramatsu: J. Biochem., 64, 521-531 (1968).

11) O. Touster: in "Methods in Enzymology" (ed. by V. Ginsburg), Vol. 50, Academic Press, New York, 1978, pp. 488-494.

12) L. Roden: in "The Biochemistry of Glycoproteins and Proteoglycans" (ed. by W. J. Lennarz), Plenum Publishing Corp., New York, 1980, pp. 267-371.

13) V.A. McKusick and E.F. Neufeld: in "The Metabolic Basis of Inherited Disease" (ed. by J. B. Stanbury, J. B. Wyngaarden, D. S. Fredrickson, J. L. Goldstein, and M. S. Brown), McGraw-Hill, New York, 1983, pp. 751-777.

14) R. DeGasperi, Y.-T. Li, and S.-C. Li: J. Biol. Chem., 261, 5696-5698 (1986).

15) A. Kobata: Seikagaku, 48, 1048-1054 (1976). 